\title{
The Effectiveness of Baby Massages Using Audiovisual Approach for Improving Interactions between Mother and Infant in Kradenan, Srimulyo, Piyungan, Bantul
}

\author{
Rahmah Widyaningrum \\ Undergraduate Program of Nursing, STIKes Madani Yogyakarta \\ Corresponding author : rachma.ninov@yahoo.co.id
}

\begin{abstract}
Background: the golden period of time (0-12 months) is a critical period for infant that require good stimulation to reach normal physiological development. Baby massage is one stimulation method that was given by parents to enhance the bonding between mothers and their babies. Audio-visual technique is one of the best method to deliver information for mother to perform self-baby massage at home, further increasing attachment between them.

Purpose: to evaluatethe effectiveness of baby massages using audiovisual approach for improving interactions between mother and infant in Kradenan, Srimulyo, Piyungan, Bantul.

Methods: This was a quasi experimental design with pretest-posttest. Study was conducted from August to September 2017 using total subjects of 20 pairs of mothers and babies. The inclusion criteria were normal birthweight, 38-42 weeks gestation age, APGAR score $>7$, breastfed, and didn't have contraindication with massage procedure. Sample was divided into two groups; treatment group (audio-visual delivery) and control group (leaflet delivery). Ten subjects for treatment group were purposively recruited from Posyandu Pantang Mundur, Kradenan whereas the others were similarly recruited from Posyandu Monggang. Data was presented as frequency distribution and analyzed using independent sample t-test.
\end{abstract}

Results: There was no difference between maternal and infant interactions at the beginning of the study $(\mathrm{p}=0.16)$. After two weeks treatment, there is no significance difference between treatment and control group $(p=0.42)$. Mother and Infant bonding scorewas increased in treatment group although not significantly different $(\mathrm{p}=0.21)$.

Conclusion: Baby massage can improve bonding between mother and baby. Further study is required to asses the effectiveness of baby massage on attachment between mother and baby.

Keywords: Audio-visual method, baby massage, maternal and baby interactions

Received: February 03, 2018; Revised February 24, 2018; Accepted March 10, 2018

How to Cite: Widyaningrum, R. (2018). The Effectiveness of Baby Massages Using Audiovisual Approach for Improving Interactions between Mother and Infant in Kradenan, Srimulyo, Piyungan, Bantul. Journal Of Nursing Practice. 1(2). 53-59 


\section{BACKGROUND}

Bonding is a feeling that arises and grows in the parents of the baby. Bonding will appear when the baby is given touch, caress, and massage with the affection of his parents. Heath and Bainbridge (2006) stated that infant massage is togetherness and physical as well emotional touching between mothers and their infants. Mothers can learn to pay attention to the reactions of their babies when touched, knowing their natural instinct and preference, which makes it easier for mothers to understand and sometimes become more patient when they are unable to calm their babies. As the mother notices and recognizes her baby's reaction and responds, the baby will react and establish a positive relationship between them. The affectionate, loving massage provided by the mother will add a strong bonding connection between mother that will support the growth of the baby mentally and emotionally.

Several studies have reported beneficial effect of infant massage. Studyfrom 48 infants at term conducted by Field et al (2005), showed an increase in body weight and length after a month of massage by a baby's parents. Similar results were found in groups of premature infants who were massaged 3 times a day for 5 days, which can furhter reduce hospital time and save the cost of care for US\$ 10,000 per baby (Dieter et al., 2003). Treatment of 15 minutes massage in premature babies for 3 times a day for 10 days (when in incubator) can increase body weight by $47 \%$ compared to control group.

In general, baby massage is a massage technique that flows from head to toe of baby. The massage technique must be done smooth and softstarting from the head, face, shoulders, arms, legs, back, chest and ends in the abdomen (McGrath et al., 2007). Furthermore, there are several techniques that mother must know for individually apply the massage to infant. These techniques were based on infant age, the pressure power, massage area, frequency, and position, which can be categorized into three technique groups (Roesli, 2001; Field et al., 2004).

\section{OBJECTIVE}

This study was to measure to evaluate the Effectiveness of Baby Massages Using Audiovisual Approach for Improving Interactions between Mother and Infant in Kradenan, Srimulyo, Piyungan, Bantul.

\section{METHODS}

\section{Research design}

This was a quasi experimental design with pretest-posttest. Study was conducted from August to September 2017 using total subjects of 20 pairs of mothers and babies. Sample was divided into two groups; treatment group (audio-visual delivery) and control group (leaflet delivery). Ten subjects for treatment group were purposively recruited from Posyandu Pantang Mundur, Kradenan whereas the others were similarly recruited from Posyandu Monggang.

\section{Setting and samples}

The use of audiovisual media of infant massage is one form of maternal recognition of the benefits, goals, and guidance of movement in performing infant selfmassage by mothers for their babies. The inclusion criteria were normal birthweight (2500 grams - 4000 grams), 38-42 weeks gestation age, APGAR score $>7$, breastfed, and didn't have contraindication with massage procedure. Samples totaling 20 pairs of infants taken purposively sampling were divided into intervention groups (given infant massage video 
and performed infant massage independently) and control group (given infant massage leaflet).

\section{Data collection and instrument}

Baby mother interactions were measured before being given baby massage video and 2 weeks after mother's baby massage practice to their respective baby. Baby massage is a real action in the form of baby massage performed by the mother of the baby independently, with the help of video provided by the researchers. Baby Massage is done daily $2 \mathrm{x}$ per session 15 minutes, for 14 days. The baby massage step is divided into 3 parts: the first 5 minutes the baby is given a gentle massage in the prone position (on the head, shoulders, back, legs and arms). The second five minutes followed by flexion and extension on the arms and legs, then ended the same movement in the first session.

The instrument used is the observation sheet is a checklist of baby massage execution, made in the form of $2 \mathrm{x} /$ day table for 2 weeks. Implementation of baby massage is written with a check mark $(\sqrt{ })$ on the observation sheet. While maternal and infant interactions between mother-infants were measured using Maternal Attachment Inventory (MAI) (Muller, 1994). The questionnaire consists of 26 items of questions to the respondent to assess: 1) how the mother feels and feels in general about the proximity of his interaction with the baby; 2) perceived by the mother; and 3) the situation experienced by mother and baby. Answers were scored between 1 (never) to 4 (always / often) total score ranges between 26 to 104 . The validity score is 0.76 and the reliability score 0.90 .

\section{Data analysis}

Data analysis result of research done quantitatively according to research purpose, data analysis used in this research using descriptive analysis (univariat). Demographic characteristics are calculated on a percentage and mean basis. While bivariate analysis using paired sample t-test to compare the measurement in each (one) group. While independent paired sample $t$ test was used to compare between groups (intervention and control), the difference between the two groups of pretest and posttest mean values. Furthermore, the discussion of the research results obtained.

\section{Ethical considerations}

Ethical considerationstest of this research is obtained from the ethics committee poltekeskemenkesyogyakarta. Informed consent was obtained from each respondent either verbally or in writing filled by the mother regarding her approval in participating in this research. The mother of the infant receives information about the benefits of following this research and has the right to accept, reject or discontinue the study. No sponsorship of any product, researcher uses video of personal work.

\section{RESULTS}

\section{Subjects characteristics}

This research was conducted on August - September 2017 at PosyanduPantang Mundur,Kradenan (treatment group) and PosyanduBalitaMonggang (control group). The samples were purposive sampling with 20 mothers and babies, 10 mothers each for treatment group and control group. 
Table 1. Characteristics of respondents in PosyanduPantang Mundur Kradenan, Srimulyo, PiyunganBantul $(\mathrm{n}=20)$

\begin{tabular}{|c|c|c|c|c|}
\hline \multirow{2}{*}{$\begin{array}{l}\text { Characteristics } \\
\text { Mothers Characteristic }\end{array}$} & \multicolumn{2}{|c|}{ Intervension group } & \multicolumn{2}{|c|}{ Control group } \\
\hline & $\mathrm{n}$ & $(\%)$ & $\mathrm{N}$ & $(\%)$ \\
\hline \multicolumn{5}{|l|}{ 1. Age } \\
\hline$<20$ years old & 0 & 0 & 0 & 0 \\
\hline $20-29$ years old & 3 & 30 & 4 & 40 \\
\hline $30-39$ years old & 6 & 60 & 6 & 60 \\
\hline$>40$ years old & 1 & 10 & 0 & 00 \\
\hline \multicolumn{5}{|l|}{ 2. Education level } \\
\hline SMP elementary & 2 & 20 & 1 & 10 \\
\hline SMA high school & 7 & 70 & 4 & 40 \\
\hline University & 1 & 10 & 5 & 50 \\
\hline \multicolumn{5}{|l|}{ 3. Occupation } \\
\hline House wife & 9 & 90 & 9 & 90 \\
\hline Civil servant & 0 & 0 & 1 & 10 \\
\hline Private sectors & 1 & 10 & 0 & 0 \\
\hline \multicolumn{5}{|l|}{ 4. Income } \\
\hline$<1.125 .000$ & 2 & 20 & 1 & 10 \\
\hline $1.125 .000-3.000 .000$ & 7 & 70 & 9 & 90 \\
\hline$>3.000 .000$ & 1 & 10 & 0 & 0 \\
\hline Babies Characteristic & $\mathrm{n}$ & $(\%)$ & $\mathrm{N}$ & $(\%)$ \\
\hline \multicolumn{5}{|l|}{ 1. Age } \\
\hline 0-6 months & 5 & 50 & 5 & 50 \\
\hline 7-12 months & 1 & 10 & 3 & 30 \\
\hline 13-18 months & 4 & 40 & 2 & 20 \\
\hline \multicolumn{5}{|l|}{ 2. Gender of baby } \\
\hline Female & 3 & 30 & 4 & 40 \\
\hline Male & 7 & 70 & 6 & 60 \\
\hline \multicolumn{5}{|l|}{ 3. Z Score } \\
\hline$<-2 \mathrm{SD}$ & 0 & 0 & 0 & 0 \\
\hline$-2 \mathrm{sd}+2 \mathrm{SD}$ & 10 & 100 & 10 & 100 \\
\hline$>+2 \mathrm{SD}$ & 0 & 0 & 0 & 0 \\
\hline
\end{tabular}

Source: primary data, 2017

Based on Table 1 on mothers characteristic shows that the majority of maternal age range 30-39 years is $6(60 \%)$, whereas the last education of mother of majority is SMA (7) $(70 \%)$ with job almost entirely as housewife (IRT) a total of 9 people $(90 \%)$, and the income of most mothers range $1,125,000$ to $3,000,000$ a total of 7 people $(70 \%)$. The babies characteristic indicate that the majority of children in the category of infants are between 0-6 months and 5 people (50\%), with the majority sex is 7 men (70\%), and all children have TB / BB with Z-score calculation between -2 to +2 SD number of 10 people $(100 \%)$.

\section{Interactions between Mother and Infant}

The results of statistical analysis showed that was no difference between maternal and infant interactions at the beginning of the study $(\mathrm{p}=0.16)$. After two weeks treatment, there is no significance difference between treatment and control group $(p=0.42)$. Mother 
and Infant bonding score was increased in treatment group although not significantly different $(p=0.21)$. This suggests that intervention in the form of interaction video delivery is not effective in improving the interaction between mother and baby.

Table 2. Statistical analysis of research results

\begin{tabular}{|c|c|c|c|c|}
\hline No & Information & Control group & Treatment group & Significancy (p) $)^{\#}$ \\
\hline 1 & Pre-test & $3,85 \pm 0,11$ & $3,75 \pm 0,16$ & 0,16 \\
\hline 2 & Post-test & $3,78 \pm 0,16$ & $3,83 \pm 0,11$ & 0,42 \\
\hline \multicolumn{2}{|c|}{ Signifikansi $(p)^{\$}$} & 0,11 & 0,21 & \\
\hline
\end{tabular}

\#independent sample $\mathrm{t}$-test statistical analysis

\$paired sample t-teststatistical analysis

Based on data analysis, there was an increase of adherence level between mother and infant in the treatment group. The results of this study are consistent with research conducted by Lee (2006) and Gurol and Polat (2012), which reported that an increase in the level of adhesions between mothers and infants in a group of mothers who were given the ability or skill to do infant massage. Psychological touch of mother will increase the interaction between mother and baby which will indirectly affect health status and baby response to mother's voice and touch (Onozawa et al., 2001; Moore and Anderson, 2007). Studies have also shown that infant massage can reducing maternal stress levels such as in mothers with low socioeconomic levels (Glover et al., 2002, Chiu and Anderson, 2009).

\section{DISCUSSION}

Baby massage is one of the traditional activities performed in several countries such as Africa and Asia. A study conducted by Darmstadt and Saha (2002) reported that 96\% of nurses in Bangladesh's Hospitalhas practice infant massage 1-3 times a day using mustard oil (Brassicaceae). The practice of infants massage has been reported to have several benefits such as increasing infant weight, improving sleep quality, increasing essential fatty acids in the body and preventing hypothermia (Kulkarni et al., 2010). Another study showed that infant massage with oil smear was able to reduce deaths because of nosocomial infections by $41 \%$ (Darmstadt et al., 2008). In addition, infant massage is also useful for improving the level of adherence between mother and baby (Lee, 2006; Gurol and Polat, 2012).

Although this study finds improvement, there are some disadvantages. First, the study did not look at maternal compliance rates in the treatment group in performing home massage practices. This leads to an insignificant increase in scores or values between mother and infant closeness. According to Kusbiantoro (2014), mother's behavior in practicing baby massage was influenced by mother's knowledge factor and family support. This study did not measure maternal knowledge of infant massage or family support, so control of these two variables needs to be done in subsequent research.

The second factor is the duration of intervention. This study was conducted in just 2 weeks, where the provision of this intervention is still not able to increase mother awareness. Studies show that the health interventions used to change behavior and give effect at least 3 months to 12 months of intervention (Jepson et al., 2010). Therefore, studies with a long duration and controlled need to be done to determine the effectiveness of infant massage in improving the interaction between mother and baby.

Audio-visual aids are those instructional devices which are used in the classroom to encourage learning and make it easier and interesting. The material like charts, map, 
models, film strip, projectors radio, television etc called instructional aids (Rather, 2004). Audio-visual aids are devices present unit of knowledge through auditory of visual. Stimuli both with a view to help learning (Singh, 2005). Audio-visual aids are valuable tools in education more so, in the field of health education as these have a long-lasting impression on the target population. Video enhances, dramatizes, and brings a sense of realism, which can have a great impact on the population (Naseem shah et al, 2016).

\section{CONCLUSION}

The conclusion of this study was the intervention of baby massage can improve the closeness between mother and baby. Further studies with better and controlled designs still need to be done to see the effectiveness of infant massage intervention with regard to confounding or external variables.

\section{ACKNOWLEDGMENTS}

Researchers are grateful to all mothers who participated in this study. This study was funded by Private Higher Education Coordinator, Region V, Yogyakarta Province.

\section{REFERENCES}

Chiu SH dan Anderson GC. 2009. Effect of early skin-to-skin contact on mother-preterm infant interaction through 18 months: Randomized controlled trial. nternational Journal of Nursing Studies; 46:1168-1180.

Darmstadt GL, Saha SK, Ahmed AS, Ahmed S, Chowdhury MA, Law PA, Rosenberg RE, Black RE, Santosham M. 2008. Effect of skin barrier therapy on neonatal mortality rates in preterm infants in Bangladesh: a randomized, controlled, clinical trial. Pediatrics; 121(3): 522-9. doi: 10.1542/peds.2007-0213.

Darmstadt, G.L. dan Saha S.K. 2002. Traditional practice of oil massage of neonates in Bangladesh. J Health Popul Nutr.; 20(2):184-8.

Dieter, J.N.I., Field, T.M, Hernandez-Reif, M., Emory, E.K \& Redzepi, M. 2003. Stable preterm infants gain more weight and sleep less after five days of massage therapy. $J$ Pediatr Psychol, 28(6):403-411.

Field, T M. 2003. Stimulation of preterm infants. Pediatr Rev;24:4-11.

Field, T.M, Diego, M. \& Hernandez-Reif, M. 2005. Massage therapy research. Dev Rev, 27(1):75-89

Glover V, Onozawa K, Hodgkinson A. 2002. Benefits of infant massage for mothers with postnatal depression. Seminars in Neonatology; 7: 495-500.

Gurol, A dan Polat S. 2012. The Effects of Baby Massage on Attachment between Mother and their Infants. Asian Nursing Research; 6(1): 35-41.

Heath, A. \& BainBridge, N. 2006. Baby Massage Kekuatan Menenangkan dari Sentuhan. Jakarta: Dian Rakyat.

Jepson RG, Harris FM, Platt S, Tannahil C. 2010. The effectiveness of interventions to change six health behaviours: a review of reviews. BMC Public Health; 10:538.

Kulkarni A, Kaushik JS, Gupta P, Sharma H, Agrawal RK. 2010. Massage and Touch Therapy in Neonates: The Current Evidence. Indian Pediatrics; 47: 771-776.

Lee, H.K. 2006. The effects of infant massage on weight, height, and mother-infant interaction. Journal of Korean Academy of Nursing; 36: 1331-39.

McGrath, J.M, Thillet, M. \& Cleave, L.V. 2007. Parent delivered infant massage: are we truly ready for implementation? Newborn infant Nurs Rev, 7(1):39-46 
Naseem shah, Vijay Prakash Mathur, Tanupriya Gupta. Effectiveness of an educational video in improving oral health knowledge in a hospital setting. Indian J Dent. 2016 Apr-Jun; 7 (2): 70-75.

Onozawa K, Glover V, Adams D, Modi N, Kumar RC. 2001. Infant massage improves mother-infant interaction for mothers with postnatal depression. Journal of Affective Disorders; 63: 201-207.

Rasul, S., Bukhsh, Q., Batool, S. 2011. A study to analyze the effectiveness of audiovisual aids in teaching learning process at university level. Journal of Procedia, Social and Behavioral Sciences 28 (2011) 78-81.

Rather, AR. 2004. Essentials intructional technology, published by darya gaj New Delhi.

Roesli, U. 2001. Pedoman pijat bayi prematur dan bayi usia $0-3$ bulan. Jakarta: Trubus Agriwidya

Singh, Y. 2005. Instructional technology in education, published by darya gaj New Delhi. 